\title{
Extracellular enzyme activity and uptake of carbon and nitrogen along an estuarine salinity and nutrient gradient
}

\author{
Margaret R. Mulholland ${ }^{1,3, *}$, Cindy Lee ${ }^{1}$, Patricia M. Glibert ${ }^{2}$ \\ ${ }^{1}$ Marine Sciences Research Center, Stony Brook University, Stony Brook, New York 11794-5000, USA \\ ${ }^{2}$ Horn Point Laboratory, University of Maryland Center for Environmental Science, PO Box 775, Cambridge, \\ Maryland 21613, USA \\ ${ }^{3}$ Present address: Department of Ocean, Earth and Atmospheric Sciences, Old Dominion University, Norfolk, \\ Virginia 23529-0276, USA
}

\begin{abstract}
Amino acid oxidation (AAO) and peptide hydrolysis (PH) are processes affecting the recycling of organic material and nutrients. We compared extracellular AAO and $\mathrm{PH}$ rates to $\mathrm{C}$ and $\mathrm{N}$ uptake rates along estuarine gradients of salinity, nutrients and productivity in the Pocomoke River, a subestuary of the Chesapeake Bay. This estuary is seasonally depleted in inorganic $\mathrm{N}$, and rich in dissolved organic material (DOM) throughout the year. $\mathrm{AAO}, \mathrm{PH}$, and $\mathrm{N}$ uptake rates measured in 1999 and 2000 were not limited to particular size fractions measured, or to auto- or heterotrophic groups of organisms. At a station near the turbidity maximum, where chlorophyll a biomass was highest, smaller $(<1.2 \mu \mathrm{m})$ size-fractions contributed $<20 \%$ of the AAO in May and up to $80 \%$ in August when AAO rates were 10 times lower. Most PH was in the larger ( $>1.2 \mu \mathrm{m})$ size-fraction, except at the least saline station in August of both years. Rates of AAO and PH were not linearly correlated with each other seasonally or spatially. Uptake of $\mathrm{NH}_{4}{ }^{+}$dominated total $\mathrm{N}$ uptake $(>50 \%)$ at all but the freshwater station, although uptake of organic compounds was measurable at all sites. Rates of dissolved free amino acid uptake, measured using dually labeled compounds, were substantial (up to $11 \%$ of the total $\mathrm{N}$ uptake) and contributed both $\mathrm{C}$ and $\mathrm{N}$ for growth. Dual labels unambiguously demonstrated that uptake rates of amino acid $\mathrm{C}$ and $\mathrm{N}$ were uncoupled; amino acid $\mathrm{N}$ was taken up preferentially to amino acid $\mathrm{C}$ even when rates were corrected for $\mathrm{N}$ uptake from AAO. Conceptual models of DOM cycling should include the realization that enzymatic processes and uptake of DOM occur in both 'microbial' and larger size fractions. Thus, competition between bacteria and phytoplankton mixotrophs may be an important factor determining the relative uptake of $\mathrm{C}$ and $\mathrm{N}$ from amino acids and other organic substrates.
\end{abstract}

KEY WORDS: Amino acid oxidation $\cdot$ Peptide hydrolysis $\cdot$ DOM cycling $\cdot \mathrm{N}$ uptake $\cdot \mathrm{C}$ uptake Resale or republication not permitted without written consent of the publisher

\section{INTRODUCTION}

Estuaries are highly productive ecosystems where concentrations of dissolved organic matter (DOM) and particulate organic matter (POM) can be quite high. Freshwater end members tend to have particularly high concentrations of DOM, much of which is terrestrially derived (Hedges et al. 1997, Hopkinson et al. 1998). However, the availability of many components of the DOM pool for uptake by organisms is unknown because DOM is a complex mixture of compounds, most of which are uncharacterized (Hansell \& Carlson 2002). Because of this complexity, a variety of different substrate-specific extracellular enzymes are necessary to remineralize DOM in nature (Hoppe 1991) and recycle material for microorganism growth. Particularly important are extracellular enzymes that degrade large polymeric biomolecules to small, labile com- 
pounds that can be taken up by microorganisms. The rates at which they function may limit the availability of labile compounds in some environments (Chróst 1991).

Two processes whereby proteins, peptides or amino acids are degraded extracellularly are amino acid oxidation (AAO) and peptide hydrolysis (PH). Both bacteria and phytoplankton can take up $\mathrm{NH}_{4}{ }^{+}$and free amino acids (Antia et al. 1991, Kirchman 2000), which are produced by these reactions. Extracellular AAO has been shown to occur in a wide range of taxonomically diverse phytoplankton and in natural assemblages of microbial organisms (Palenik et al. 1990a,b, Pantoja \& Lee 1994, Mulholland et al. 1998) including those dominated by bloom species (Mulholland et al. 2002). Extracellular PH is thought to produce smaller peptides and amino acids from larger compounds such as proteins and polypeptides in oceanic (Hollibaugh \& Azam 1983, Keil \& Kirchman 1992, Taylor 1995) and coastal (Hoppe 1983, 1991, Pantoja \& Lee 1999) marine systems, including those seasonally dominated by mixotrophic organisms (Mulholland et al. 2002, Stoecker \& Gustafson 2003). Little is known about how rates of extracellular enzymatic reactions affect available nutrient pools in nutrient- and organic-rich estuaries and tributaries.

Proteins typically represent at least $75 \%$ of phytoplankton cell N (Dortch et al. 1984, Nguyen \& Harvey 1994) and $80 \%$ of bacterial cell N (Kirchman 2000). In oceanic systems, little of the protein produced in the euphotic zone reaches the sediments due to water-column degradation and recycling processes (Lee \& Cronin 1984, Smith et al. 1992, Hoppe et al. 1993). Similarly, proteins and peptides are rapidly degraded in estuarine systems (Nguyen \& Harvey 1997). Upon grazing, senescence, death, or cell lysis, particulate proteins may enter the DOM pool, where they are subject to further degradation. Dissolved combined amino acids (DCAA) typically represent between 5 and $20 \%$ of the dissolved organic nitrogen (DON) pool and 3 to $4 \%$ of the dissolved organic carbon (DOC) pool in seawater (Sharp 1983). DCAA are measured only after acid hydrolysis, and include peptides, proteins and amino acids that are adsorbed or bound in some way. Both DCAA and dissolved free amino acid (DFAA) concentrations are higher in estuarine systems than in oceanic systems and are generally correlated with primary productivity (Sellner \& Nealley 1997, Bronk et al. 1998, Nagata 2000).

Many microorganisms can use DOM to meet some or all of their energy or nutritional demands for growth. In addition to bacteria, a variety of phytoplankton species directly supplement their nutrition by taking up and using organic compounds (e.g. Paerl 1988, Berg et al. 1997, Lewitus et al. 1999, Glibert et al. 2001). In partic- ular, many nuisance algal species exhibit positive growth responses to the addition of small organic compounds (Lewitus \& Kana 1994, Berg et al. 1997, Gobler \& Sañudo-Wilhelmy 2001). Thus, an important question in productive, organic-rich systems is to what extent does organic matter contribute to auto- and heterotrophic microbial nutrition relative to inorganic nutrients?

Here we explore the contribution of $\mathrm{AAO}$ and $\mathrm{PH}$ to the $\mathrm{C}$ and $\mathrm{N}$ nutrition of autotrophic and heterotrophic plankton in the Pocomoke River, a tributary of the Chesapeake Bay on Maryland's eastern shore. We examine the contribution of $\mathrm{AAO}$ and $\mathrm{PH}$ to the turnover of DFAA and DCAA, and relative to the uptake of DFAA and inorganic N compounds.

\section{MATERIALS AND METHODS}

Sampling site and field methods. The Pocomoke River drains largely agricultural land and has relatively little direct nitrogen input from point sources (Maryland Department of Natural Resources 1998, Glibert et al. 2001). Pocomoke waters are rich in DOM, including DON (Glibert et al. 2001). Samples were collected along a salinity transect of the river from its salty mouth to freshwater upriver (Fig. 1). The mouth of the river (e.g. Stn 9A) was sampled more intensively because it is near the turbidity maximum. Experiments were conducted during the months of May and August in 1999 and 2000. From a small boat, water samples were pumped from just below the surface $(<0.5 \mathrm{~m})$ into 10 or 201 acid-washed plastic carboys, except as noted below. Samples were transported on ice to Horn Point Laboratory for sample-processing, which began within 4 to $6 \mathrm{~h}$ of collection.

Rate measurements and analytical methods. During all sampling periods, rates of enzyme activity in different size-fractions were compared. Direct uptake rates of inorganic and organic nitrogenous nutrients $\left(\mathrm{NH}_{4}{ }^{+}\right.$, $\mathrm{NO}_{3}{ }^{-}$, urea and amino acids) were measured on selected samples. In addition, at one site, variations in rates as a function of sample-handling protocols were assessed. The approaches to determine each of these rates are described in the following subsections.

Amino acid oxidation and peptide hydrolysis rates: Rates of AAO and $\mathrm{PH}$ were measured using the fluorescent analogs, lucifer yellow anhydride (LYA)-lysine and LYA-tetraalanine (LYA-ala4), respectively (Pantoja et al. 1993, 1997). Rates were measured over time as the disappearance of substrate and/or appearance of products. Incubations were initiated by adding substrates to a final concentration of $98 \mathrm{nM}$ LYA-lysine or $95 \mathrm{nM}$ LYA-ala4. Subsamples were collected at 0, $30 \mathrm{~min}, 1 \mathrm{~h}$ and 10 additional times over the course 


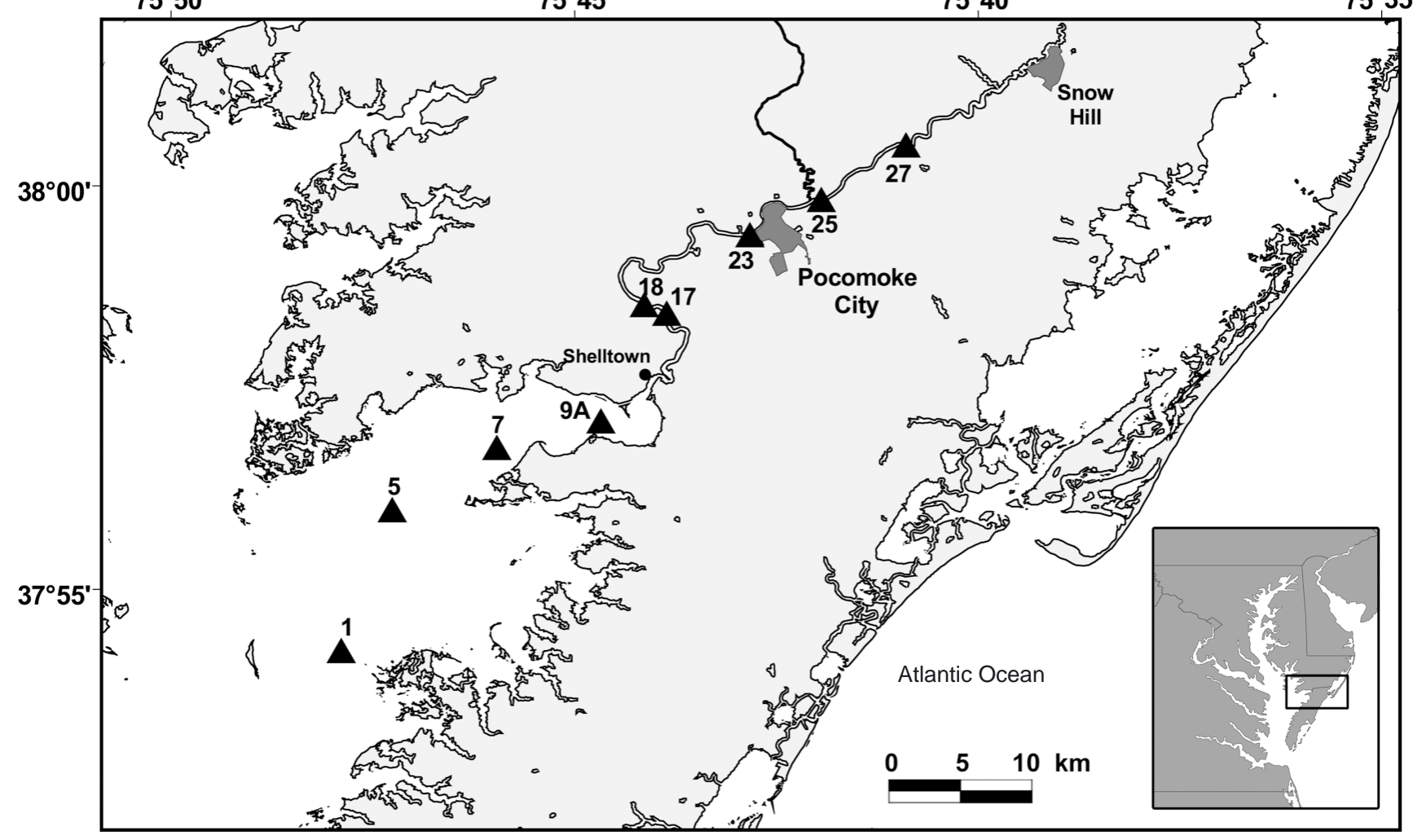

Fig. 1. The Pocomoke River estuary, showing sampling staions. Inset: Chesapeake Bay region

of 2 d during May 1999. In later assays, incubations lasted only 4 to $6 \mathrm{~h}$. At each time-point, samples were syringe-filtered $(0.2 \mu \mathrm{m})$ to terminate activity and then frozen until analysis. LYA-lysine, LYA-ala4, and their derivatives were quantified by high-performance liquid chromatography (HPLC). Identification and quantification of peaks was accomplished using authentic standards synthesized in the laboratory (Pantoja et al. $1993,1997)$. First-order rate constants $(k)$ were calculated from time-course incubations. Means and standard deviations were calculated from triplicate incubations, and standard deviations were usually less than $5 \%$. Rates of AAO and PH were estimated by multiplying $k$ by the relevant dissolved pool, DFAA, to estimate AAO, and DCAA (total hydrolysable amino acids [THAA] minus DFAA) to estimate PH. Turnover times of particulate pools due to AAO and $\mathrm{PH}$ were calculated by multiplying $k$ by the relevant particulate pool, either particulate organic C (POC) or particulate organic N (PON).

Size-fractionation experiments: To determine the relative size-class of plankton contributing most significantly to both $\mathrm{AAO}$ and $\mathrm{PH}$, measurements were made on size-fractionated samples selected based on the size of functional groups (e.g. bacteria, small and large phytoplankton) and revised based on initial results. Triplicate acid-cleaned polycarbonate bottles were filled with either 25 or $50 \mathrm{ml}$ of water from each sizefraction. In May 1999, water was collected from Stns 9A and 17 (Fig. 1), size-fractionated by gentle vacuum filtration $(<125 \mathrm{~mm} \mathrm{Hg})$, and $\mathrm{AAO}$ and $\mathrm{PH}$ rates measured in $<0.2 \mu \mathrm{m}$ (abiotic control), $<20 \mu \mathrm{m}$ (bacteria and small phytoplankton) and whole-water (all plankton) fractions. In August 1999, water was collected from Stns 1, 9A, 18, and 25 (Fig. 1), and rates measured in $<0.2$, $<1.0 \mu \mathrm{m}$ (primarily bacteria) and whole-water size-fractions. This allowed resolution of enzyme activity in the bacterial size-fraction. Because no activity was observed in the $<0.2 \mu \mathrm{m}$ size-fraction in the 1999 samples, this size-fraction was omitted in 2000. In May and August 2000, water was collected from Stns 5 or 7, 9A, 18, and 27 and size-fractionated into $<1.2 \mu \mathrm{m}$ (primarily bacteria), <10 $\mu \mathrm{m}$ (bacteria and small phytoplankton) and whole-water fractions for rate measurements. The same high- and low-salinity end-member stations (1 through 7 and 23 through 27, respectively) were not sampled each time because of weather constraints.

Sample-handling effects: On 2 occasions (May and August 2000), experiments were conducted to determine the potential impact of transit time on enzymatic 
reaction rates. Samples were collected from Stn 9A, and $\mathrm{AAO}$ and $\mathrm{PH}$ rate measurements were initiated both on the boat dock, within 15 min of sample collection, and after the sample had been transported to the laboratory 4 to $6 \mathrm{~h}$ after sample collection.

Inorganic nitrogen and urea uptake: In May and August 2000, uptake rates of ${ }^{15} \mathrm{~N}$-labeled $\mathrm{NH}_{4}{ }^{+}, \mathrm{NO}_{3}{ }^{-}$, and urea were measured in whole water and in $<10.0 \mu \mathrm{m}$ size-fractionated water (bacteria and small phytoplankton). Experiments were initiated by adding tracer concentrations $(10 \%$ of the ambient pool, or

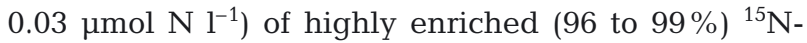
labelled substrates to samples in acid-clean polycarbonate bottles. After $1 \mathrm{~h}$ or less, incubations were terminated by gentle filtration $(<125 \mathrm{~mm} \mathrm{Hg})$ through pre-combusted $\left(450^{\circ} \mathrm{C}\right.$ for $2 \mathrm{~h}$ ) $\mathrm{GF} / \mathrm{F}$ filters; the filters were rinsed with filtered seawater and frozen until analysis. Isotope ratios were measured on a Europa 20/20 isotope-ratio mass spectrometer equipped with an elemental analyzer. Uptake rates were calculated using the equations of Glibert \& Capone (1993).

Amino acid uptake: Direct uptake of amino acids was measured using ${ }^{14} \mathrm{C}$-labeled glutamate (August 1999), ${ }^{15} \mathrm{~N}$-labeled glutamate (May 2000), and ${ }^{13} \mathrm{C}$ and ${ }^{15} \mathrm{~N}$ dually labeled glutamate (August 2000). Uptake of uniformly labeled ${ }^{14} \mathrm{C}$-glutamate was measured using standard methods (Lee 1992, Jørgensen et al. 1993) and 20 min incubations. Samples were incubated in triplicate after adding $9 \mathrm{nCi} \mathrm{ml}^{-1}$ of radiolabeled substrate. All original label added was accounted for as either $\mathrm{CO}_{2}$ respired, organic carbon incorporated into microbial biomass (using $0.2 \mu \mathrm{m}$ Nuclepore filters), or unused label. Rates were estimated by multiplying the percent incorporated or respired per unit time by the total DFAA pool.

Stable isotope experiments were initiated by adding

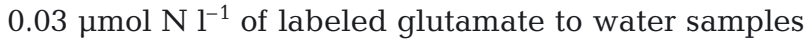
that had been placed in acid-clean polycarbonate bottles. The $\mathrm{N}$ atoms of the ${ }^{15} \mathrm{~N}$-labeled glutamate and the $\mathrm{C}$ and $\mathrm{N}$ atoms of dual-labeled glutamate were uniformly labeled; all $\mathrm{C}$ and $\mathrm{N}$ labels were highly enriched $\left(98 \%{ }^{13} \mathrm{C}\right.$ and 96 to $\left.99 \%{ }^{15} \mathrm{~N}\right)$. After $1 \mathrm{~h}$ or less of incubation, samples were processed as described above for inorganic $\mathrm{N}$ and urea uptake using $0.7 \mu \mathrm{m}$ $\mathrm{GF} / \mathrm{F}$ filters. Amino acid uptake rates were calculated using DFAA as the relevant ambient nutrient pool. It was assumed that the relative labilities of individual amino acids were equal. The $\mathrm{C}: \mathrm{N}$ ratio of the ambient DFAA pool was estimated based on the individual amino acid composition determined from HPLC analyses (see subsection below) and was used to calculate the relative $\mathrm{C}$ and $\mathrm{N}$ uptake from amino acids.

Fate of nitrogen from cell-surface oxidation: The fate of $\mathrm{N}$ released from cell-surface AAO was directly assessed through the development and application of an amino acid tagged with both LYA and with ${ }^{15} \mathrm{~N}$. This compound was synthesized by condensing ${ }^{15} \mathrm{~N}$-labeled lysine with LYA as described by Pantoja et al. (1993). Uptake of ${ }^{15} \mathrm{~N}$ derived directly from ${ }^{15} \mathrm{~N}$-labeled LYAlysine oxidation was measured in August 1999. LYA-

${ }^{15} \mathrm{~N}$-lysine was added to samples in the same quantity as for experiments conducted with unlabeled LYAlysine, as described earlier. After $1 \mathrm{~h}, 25 \mathrm{ml}$ samples were filtered onto pre-combusted Whatman GF/F filters and the filters were frozen until processing. Isotopic ratios were measured by isotope-ratio mass spectrometry, as described earlier. To calculate the uptake of ${ }^{15} \mathrm{~N}$ derived from the oxidation of LYA- ${ }^{15} \mathrm{~N}$-lysine, it was assumed that ${ }^{15} \mathrm{NH}_{4}{ }^{+}$was the only labeled oxidation product. The rate of AAO we measured was used to calculate ${ }^{15} \mathrm{NH}_{4}{ }^{+}$production during the $1 \mathrm{~h}$ incubation period. The atom \% enrichment of the ambient $\mathrm{NH}_{4}{ }^{+}$pool was then estimated based on the production of ${ }^{15} \mathrm{NH}_{4}{ }^{+}$from AAO. The uptake rate of $\mathrm{NH}_{4}{ }^{+}$released from amino acids was then calculated using the equations of Glibert \& Capone (1993).

Dissolved nutrient, amino acid and biomass concentrations: Samples were filtered through precombusted Whatman GF/F filters upon arrival in the laboratory. Chlorophyll a concentrations were determined on particulate material by fluorometry (Parsons et al. 1984). Concentrations of PON and POC were determined on a Control Equipment CHN analyzer. Filtrates were placed into combusted scintillation vials or sterile microcentrifuge tubes and frozen for later DFAA and DCAA analyses. DFAA were measured individually by HPLC (Lindroth \& Mopper 1979, Cowie \& Hedges 1992) or as total dissolved primary amines by fluorometry (Parsons et al. 1984). Concentrations of total hydrolysable amino acids (THAA) were measured by HPLC or fluorometry after vapor-phase hydrolysis (Tsugita et al. 1987, Keil \& Kirchman 1991). DCAA were calculated as the difference between THAA and DFAA. Filtered samples for $\mathrm{NH}_{4}{ }^{+}, \mathrm{NO}_{3}{ }^{-}$and urea analyses were placed in acid-cleaned polyethylene bottles and frozen until analysis. Concentrations of $\mathrm{NH}_{4}{ }^{+}$and $\mathrm{NO}_{3}{ }^{-}$were measured using an autoanalyzer. Urea concentrations were estimated using the urease method (Parsons et al. 1984).

\section{RESULTS}

\section{Water quality parameters}

Water quality parameters and chemical concentrations measured during the study periods are presented in Table 1. August, and to a lesser extent May, temperatures were higher in 1999 than 2000. Salinity at the 
Table 1. Nutrient concentrations and biomass in surface waters of the Pocomoke River in May and August 1999 and 2000. DFAA: dissolved free amino acids; DCAA: dissolved combined amino acids

\begin{tabular}{|c|c|c|c|c|c|c|c|c|c|c|c|}
\hline Stn & $\begin{array}{l}\text { Salinity } \\
\text { (PSU) }\end{array}$ & $\begin{array}{l}\text { Temp. } \\
\left({ }^{\circ} \mathrm{C}\right)\end{array}$ & $\begin{array}{l}\mathrm{NH}_{4}^{+} \\
(\mu \mathrm{M})\end{array}$ & $\begin{array}{l}\mathrm{NO}_{3}^{-} \\
(\mu \mathrm{M})\end{array}$ & $\begin{array}{l}\text { Urea } \\
(\mu \mathrm{M})\end{array}$ & $\begin{array}{l}\text { DFAA } \\
(\mu \mathrm{M})\end{array}$ & $\begin{array}{c}\text { DCAA } \\
(\mu \mathrm{M})\end{array}$ & $\begin{array}{l}\text { POC } \\
(\mu M)\end{array}$ & $\begin{array}{l}\text { PON } \\
(\mu M)\end{array}$ & $\begin{array}{c}\text { Particulate } \\
\text { C:N }\end{array}$ & $\begin{array}{r}\text { Chl } a \\
\left(\mu \mathrm{g} \mathrm{l}^{-1}\right)\end{array}$ \\
\hline \multicolumn{12}{|c|}{14 May 1999} \\
\hline $9 \mathrm{~A}$ & 7.50 & 22.4 & 0.52 & 0.56 & 0 & 0.30 & 2.06 & 626 & 62.4 & 10.0 & 23.3 \\
\hline 17 & 1.50 & 22.2 & 5.32 & 27.3 & 0 & 0.09 & 2.14 & 318 & 28.3 & 11.3 & 17.5 \\
\hline \multicolumn{12}{|c|}{18 Aug 1999} \\
\hline 1 & 20.9 & 27.5 & 2.49 & 0.15 & 0.13 & 0.18 & 0.74 & 119 & 16.4 & 7.2 & 12.1 \\
\hline $9 \mathrm{~A}$ & 16.4 & 28.1 & 0.48 & 0 & 0.04 & 0.54 & 3.07 & 292 & 34.7 & 8.4 & 22.1 \\
\hline 18 & 7.02 & 28.9 & 6.29 & 7.32 & 0.38 & 0.17 & 3.82 & 244 & 24.6 & 9.9 & 19.7 \\
\hline 25 & 0.67 & 28.7 & 2.9 & 9.47 & 0.21 & 0.08 & 1.38 & 167 & 13.4 & 12.4 & 12.1 \\
\hline \multicolumn{12}{|c|}{8 Мау 2000} \\
\hline 5 & 16.3 & 19.9 & 0.46 & 0.2 & 0.38 & 0.57 & 2.80 & 210 & 20.6 & 8.7 & 17.6 \\
\hline $9 \mathrm{~A}$ & 10.4 & 22.8 & 1.61 & 0.03 & 0 & 1.34 & 2.50 & 412 & 38.3 & 9.2 & 32.4 \\
\hline 18 & 0.20 & 21.1 & 4.61 & 41.7 & 0.67 & 0.22 & 1.46 & 289 & 20.6 & 12.1 & 2.83 \\
\hline 27 & 0.06 & 22.2 & 4.81 & 89.8 & 0.78 & 0.12 & 0.70 & 159 & 8.6 & 15.9 & 0.95 \\
\hline \multicolumn{12}{|c|}{21 Aug 2000} \\
\hline 7 & 10.5 & 23.3 & 1.22 & 0.12 & 0.33 & 0.63 & 3.11 & 176 & 20.1 & 8.8 & 13.3 \\
\hline $9 \mathrm{~A}$ & 4.84 & 23.0 & 0.87 & 1.19 & 0.38 & 0.25 & 2.87 & 292 & 32.2 & 9.1 & 18.6 \\
\hline 18 & 0.35 & 24.6 & 2.09 & 23.0 & 0.21 & 0.07 & 3.69 & 164 & 13.4 & 12.2 & 4.25 \\
\hline 27 & 0.03 & 22.5 & 2.87 & 39.1 & 0.86 & 0.23 & 2.36 & 119 & 7.8 & 15.1 & 2.10 \\
\hline
\end{tabular}

same or nearby stations was also generally higher in 1999 than 2000. Concentrations of DIN were much higher at the low-salinity stations and also in 2000 compared to 1999. The C:N ratio of particulate material was also highest at the freshwater stations, suggesting that inputs of C-rich, terrestrial organic material were more important upstream and/or that in situ production increased downstream. $\mathrm{NH}_{4}{ }^{+}$concentrations were lowest and chl a concentrations highest at Stn 9A, the turbidity maximum.

Concentrations of DFAA ranged between 0.07 and $1.34 \mu \mathrm{M}$ over the $2 \mathrm{yr}$ study period (Table 1), much higher than oceanic concentrations and higher than in many other estuaries (Bronk 2002 and references therein). Concentrations of DCAA were between 0.70 and $3.82 \mu \mathrm{M}$, consistent with those in other estuaries (Kirchman 2000), and showed no relationship to salinity. Aspartic acid, serine, glycine and alanine were the most abundant DFAA (data not shown), and there was no clear trend in DFAA or DCAA composition along the transects. The average $\mathrm{C}: \mathrm{N}$ ratio was 3.7:1 for the DFAA pool and 4:1 for DCAA.

\section{Rates of AAO and PH: general trends}

With the exception of August 1999, rate constants within seasons for AAO and $\mathrm{PH}$ were generally of the same order of magnitude, ranging from 0.00 to $5.15 \mathrm{~d}^{-1}$ throughout the study period (Table 2). Absolute rates for $\mathrm{PH}$ were, however, consistently higher than rates of
AAO because the DCAA pool was larger than the DFAA pool (Table 2). Rates of $\mathrm{PH}$ were also much higher in 1999 than in 2000. With the exception of 1 station in August 2000, rates of AAO were higher with higher salinity, but there was no overall correlation between AAO and salinity (Table 2). Rates of PH did not show a consistent pattern with salinity, either within experiments or overall $\left(\mathrm{R}^{2}<0.2\right)$. AAO did not correlate directly with $\mathrm{PH}$.

\section{Rates of AAO and PH: size-fractionation patterns}

In both May and August 1999, AAO and $\mathrm{PH}$ rates in the $<0.2 \mu \mathrm{m}$ size-fraction were undetectable (data not shown), suggesting that enzymes were associated with particles. The relative contribution of the $<1.0$ or $<1.2 \mu \mathrm{m}$ size-fractions to total AAO activity varied widely, but was highest at Stn 9A in August of both years (Fig. 2). Overall, rates of AAO were lower in August than in May during both years. In May 2000, the highest AAO rates were observed at Stns 5 and $9 \mathrm{~A}$, and most of this oxidation was in the $>10 \mu \mathrm{m}$ sizefraction. Although rates of AAO were not well correlated with chl a $\left(\mathrm{R}^{2}=0.2\right)$ or PON $\left(\mathrm{R}^{2}=0.57\right)$, chl a concentrations (Table 1) were generally higher at these 2 stations than upstream, and higher in May than in August. The substantial amount of activity in whole water samples suggests that AAO was associated with phytoplankton, attached bacteria or bacterial aggregates. 
Table 2. Amino acid oxidation (AAO) and peptide hydrolysis ( $\mathrm{PH}$ ) rate constants, rates and turnover times of pools affected by these 2 processes for experiments conducted in the Pocomoke River in 1999 and 2000 on whole water samples. Turnover times of DFAA and DCAA pools from AAO and PH, respectively, are the inverse of the rate constant for these processes

\begin{tabular}{|c|c|c|c|c|c|c|c|c|c|c|}
\hline \multirow[t]{2}{*}{ Stn } & \multicolumn{2}{|c|}{ Rate constants } & \multicolumn{2}{|c|}{ Rates } & \multirow{2}{*}{$\begin{array}{c}\text { DFAA turnover } \\
\text { from AAO } \\
\text { (h) }\end{array}$} & \multirow{2}{*}{$\begin{array}{l}\text { DCAA turnover } \\
\text { from } \mathrm{PH} \\
\text { (h) }\end{array}$} & \multicolumn{2}{|c|}{ POC turnover } & \multicolumn{2}{|c|}{ PON turnover } \\
\hline & $\begin{array}{l}\text { AAO } \\
\left(d^{-1}\right)\end{array}$ & $\begin{array}{c}\mathrm{PH} \\
\left(\mathrm{d}^{-1}\right)\end{array}$ & $\begin{array}{c}\mathrm{AAO} \\
\left(\mu \mathrm{M} \mathrm{d}^{-1}\right)\end{array}$ & $\begin{array}{c}\text { PH } \\
\left(\mu \mathrm{M} \mathrm{d}^{-1}\right)\end{array}$ & & & $\begin{array}{l}\text { AAO } \\
\text { (d) }\end{array}$ & $\begin{array}{l}\mathrm{PH} \\
\text { (d) }\end{array}$ & $\begin{array}{l}\text { AAO } \\
\text { (d) }\end{array}$ & $\begin{array}{l}\text { PH } \\
\text { (d) }\end{array}$ \\
\hline \multicolumn{11}{|c|}{14 Мау 1999} \\
\hline $9 \mathrm{~A}$ & 4.8 & 5.15 & 1.43 & 10.62 & 5.0 & 4.66 & 439 & 58.9 & 43.8 & 5.9 \\
\hline 17 & 1.93 & 2.28 & 0.17 & 4.89 & 12.4 & 10.5 & 1920 & 65.1 & 170 & 5.8 \\
\hline \multicolumn{11}{|c|}{18 Aug 1999} \\
\hline 1 & 0.8 & 3.82 & 0.14 & 2.83 & 30.0 & 6.28 & 830 & 42.0 & 115 & 5.8 \\
\hline $9 \mathrm{~A}$ & 0.53 & 4.89 & 0.29 & 15.03 & 45.3 & 4.91 & 1010 & 19.4 & 120 & 2.3 \\
\hline 18 & 0.35 & 4.19 & 0.06 & 15.99 & 68.6 & 5.73 & 4170 & 15.2 & 420 & 1.5 \\
\hline 25 & 0.16 & 2.19 & 0.01 & 3.03 & 150 & 11.0 & 13900 & 55.0 & 1120 & 4.4 \\
\hline \multicolumn{11}{|c|}{8 Мay 2000} \\
\hline 5 & 2.36 & 1.67 & 1.35 & 4.68 & 10.2 & 14.4 & 156 & 44.9 & 15.2 & 4.4 \\
\hline $9 \mathrm{~A}$ & 1.46 & 2.86 & 1.96 & 7.16 & 16.4 & 8.39 & 210 & 57.5 & 19.5 & 5.3 \\
\hline 18 & 0.33 & 0.68 & 0.07 & 0.99 & 72.7 & 35.3 & 3900 & 292 & 277 & 20.7 \\
\hline 27 & 0 & 0.49 & 0 & 0.34 & & 49.0 & & 465 & & 25.0 \\
\hline \multicolumn{11}{|c|}{21 Aug 2000} \\
\hline 7 & 0.10 & 0.29 & 0.06 & 0.90 & 247 & 82.8 & 2880 & 195 & 329 & 22.3 \\
\hline $9 \mathrm{~A}$ & 0.17 & 0.21 & 0.04 & 0.60 & 141 & 114 & 6870 & 485 & 758 & 53.5 \\
\hline 18 & 0.33 & 0.30 & 0.02 & 1.11 & 72.7 & 80.0 & 7090 & 148 & 579 & 12.1 \\
\hline 27 & 0.52 & 0.16 & 0.12 & 0.38 & 46.2 & 150 & 992 & 314 & 65.5 & 20.7 \\
\hline
\end{tabular}
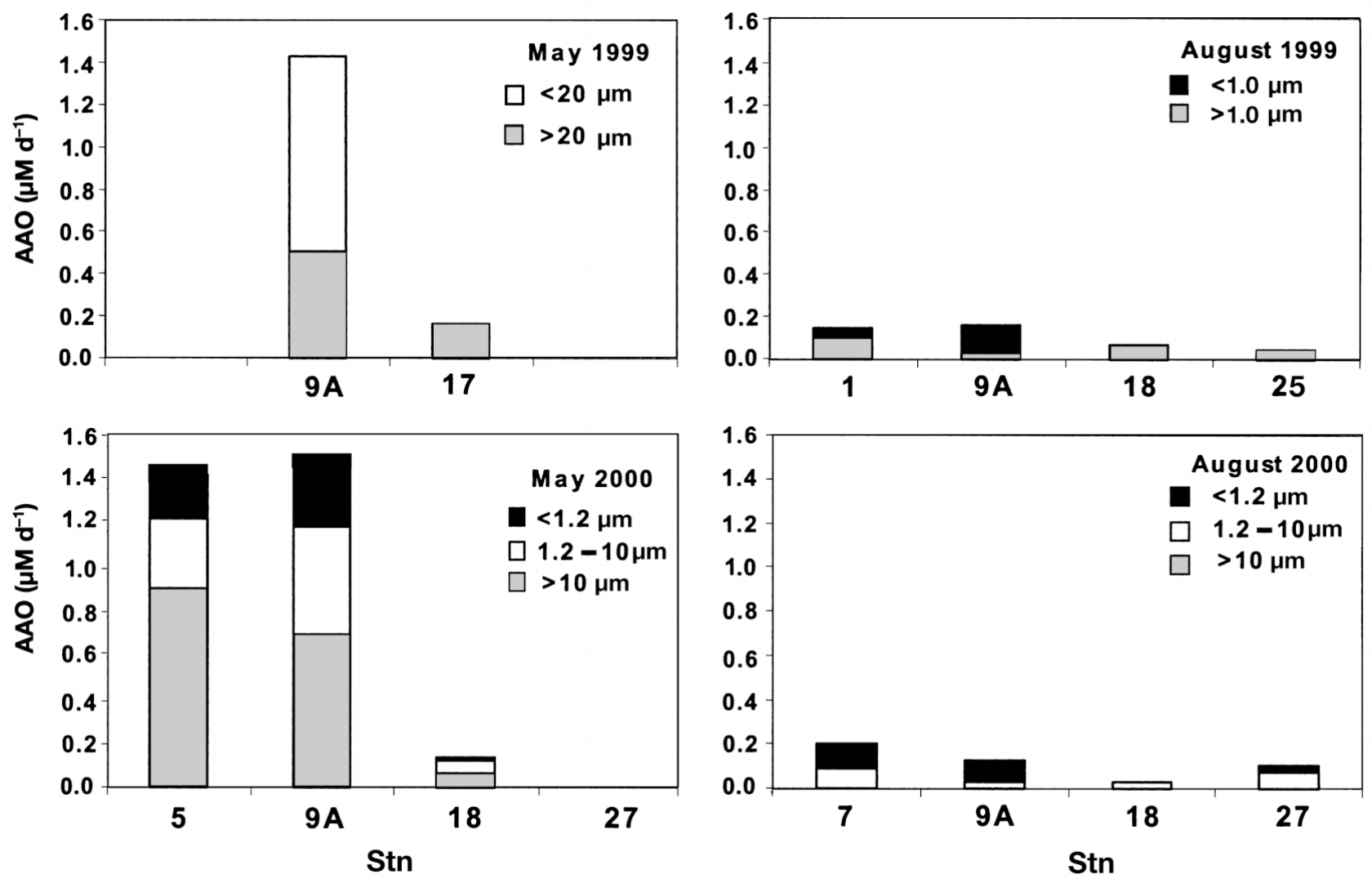

Fig. 2. Rates of amino acid oxidation (AAO) and relative contribution of each size-fraction (estimated by difference; $<1.0 \mu \mathrm{m}$ [or $<1.2$ or $<20 \mu \mathrm{m}$ ], 1.2 to $10 \mu \mathrm{m}$ and $>1,10$ or $20 \mu \mathrm{m}$ ) to total oxidation rates in whole water samples (whole bars) during May and August sampling efforts in 1999 and 2000 

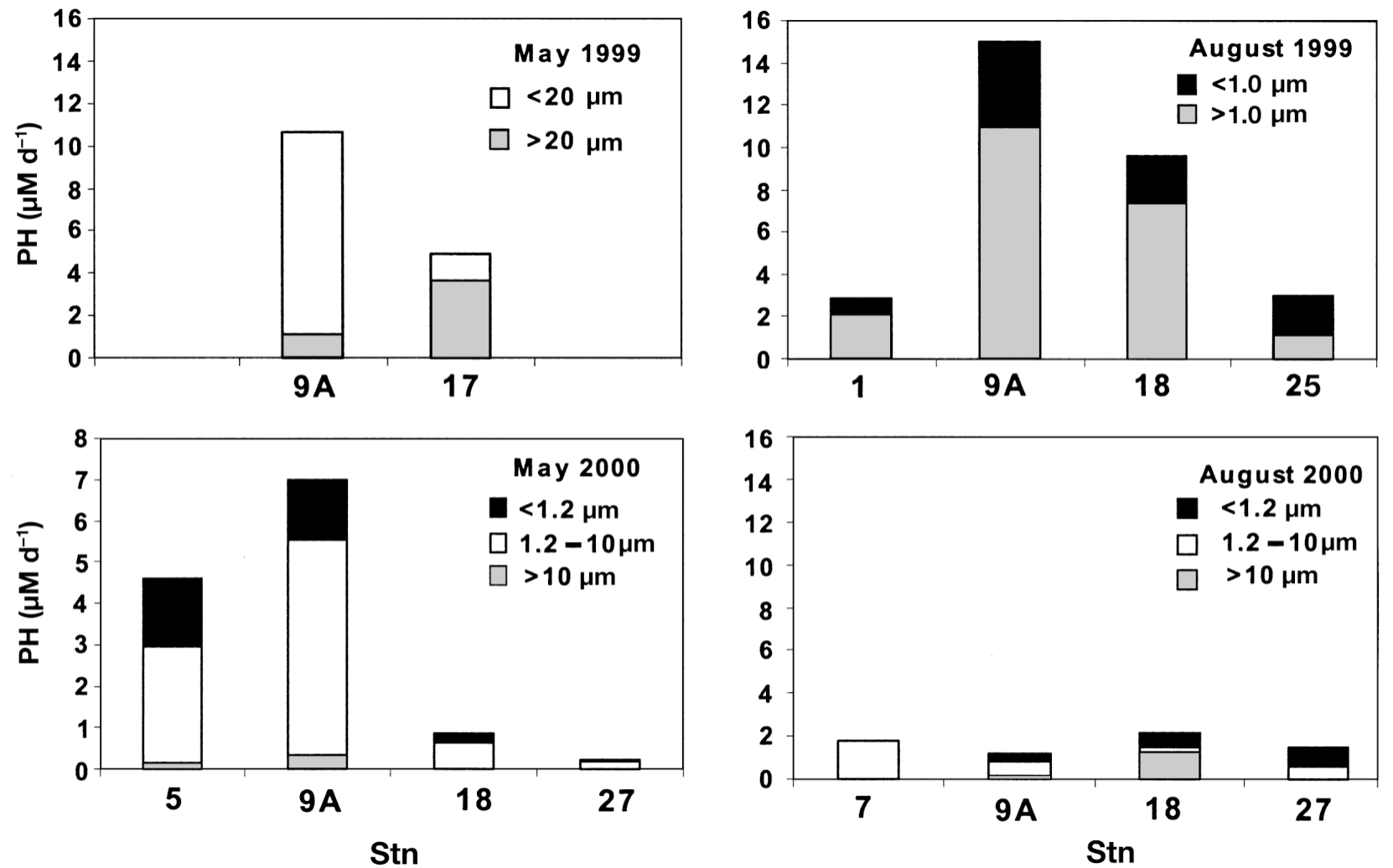

Fig. 3. Rates of peptide hydrolysis ( $\mathrm{PH}$ ) and relative contribution of each size-fraction, (estimated by difference; $<1.0 \mu \mathrm{m}$ [or $<1.2$ or $<20 \mu \mathrm{m}$ ], 1.2 to $10 \mu \mathrm{m}$ and $>1,10$ or $20 \mu \mathrm{m}$ ) to total hydrolysis rates in whole water samples (whole bars) during May and August sampling efforts in 1999 and 2000. Note scale change between 1999 and 2000 for May

Rates of $\mathrm{PH}$ in the $<1.0$ or $<1.2 \mu \mathrm{m}$ fractions, with the exception of the lowest-salinity station in August of both years, represented $<30 \%$ of total rates (Fig. 3). Unlike AAO, the 1.2 to $10 \mu \mathrm{m}$ size-fraction was the major contributor to PH in May 2000, and rates, rates of $\mathrm{PH}$ were not always higher in May than in August. Correlations between PH and DFAA or DCAA $\left(\mathrm{R}^{2}=\right.$ $0.42)$, chl a $\left(R^{2}=0.42\right)$, and PON $\left(R^{2}=0.40\right)$ were weak. While the highest rates of both AAO and $\mathrm{PH}$ were observed at low DIN concentrations, that correlation was also weak.

\section{Rates of AAO and PH: sample handling effects}

$\mathrm{AAO}$ and $\mathrm{PH}$ rate constants were substantially higher in samples that were transported to the laboratory, than in those measured immediately after sample collection (Table 3). This difference was more pronounced in May. Thus, all rates should be considered potential rates, as in situ rates were likely to have been lower than those routinely measured after transport to the laboratory.

\section{$\mathrm{N}$ uptake rates}

During 2000, total $\mathrm{N}$ uptake rates were higher (up to

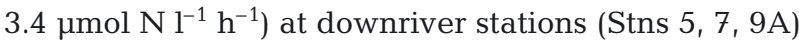
than at upriver stations $(18,27$; Fig. 4). The majority of $\mathrm{N}$ uptake $(>50 \%)$ was as $\mathrm{NH}_{4}{ }^{+}$at all but the leastsaline station. At the freshwater sites, where concen-

Table 3. Mean (with standard deviation in parentheses) amino acid oxidation (AAO) and peptide hydrolysis (PH) rate constants in whole water samples for experiments conducted on the boat dock immediately after sample collection, and in the laboratory 4 to $6 \mathrm{~h}$ after collection. Water was collected from Stn 9A in May and August 2000

\begin{tabular}{|lll|}
\hline Location & AAO $\left(\mathrm{d}^{-1}\right)$ & $\mathrm{PH}\left(\mathrm{d}^{-1}\right)$ \\
\hline May & & \\
$\quad$ Dock & $0.63(0.01)$ & $1.74(0.02)$ \\
Laboratory & $1.30(0.001)$ & $5.21(0.11)$ \\
August & & \\
$\quad$ Dock & $0.68(0.04)$ & $0.72(0.01)$ \\
Laboratory & $1.07(0.01)$ & $0.85(0.02)$ \\
\hline
\end{tabular}




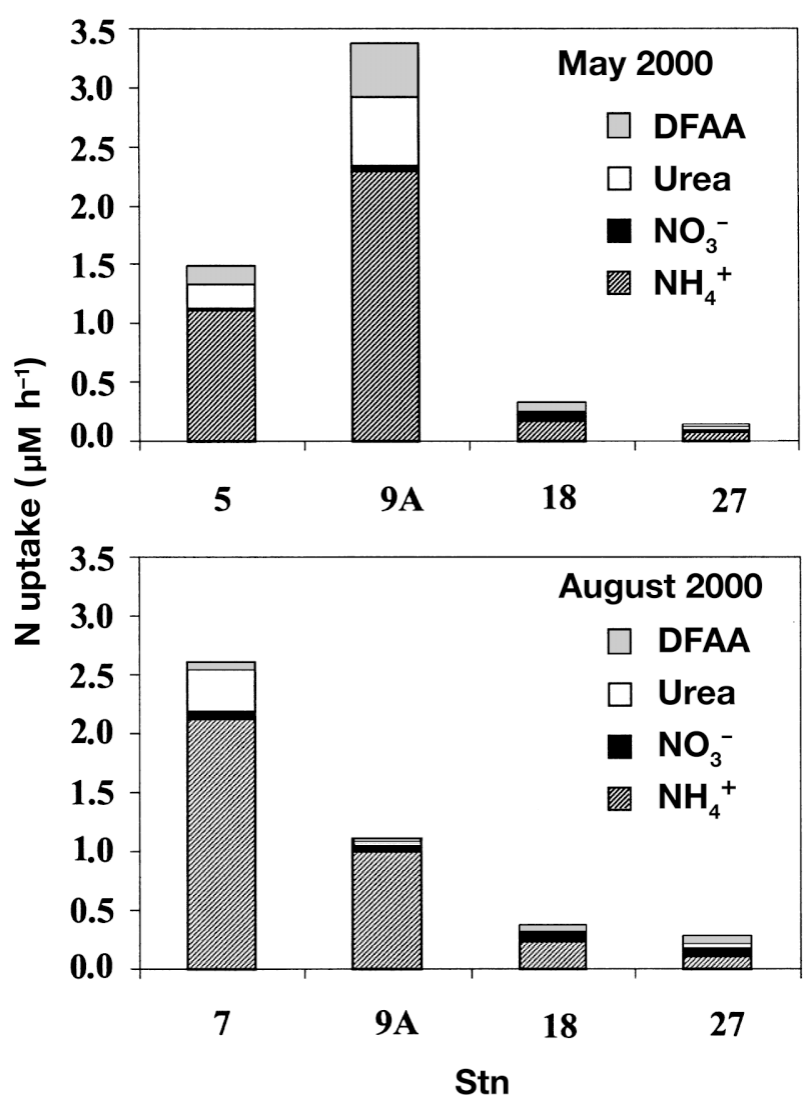

Fig. 4. Rates of total $\mathrm{N}$ uptake and relative contribution of dissolved free amino acids (DFAA), urea, $\mathrm{NH}_{4}{ }^{+}$and $\mathrm{NO}_{3}{ }^{-}$uptake to total rates along river transect in May and August 2000

trations of $\mathrm{NO}_{3}{ }^{-}$were high, rates of $\mathrm{NO}_{3}{ }^{-}$uptake were at least $25 \%$ of total $\mathrm{N}$ uptake. Rates of DFAA uptake

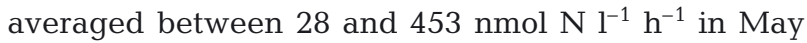
(10 to $22 \%$ of total $\mathrm{N}$ uptake) and between 26 and $62 \mathrm{nmol} \mathrm{N}^{-1} \mathrm{~h}^{-1}$ in August (2 to $22 \%$ of total N uptake) 2000. While DFAA uptake rates were similar or lower at the less-saline stations relative to the more-saline

Table 4. Percent of total (whole water) measured uptake attributable to the $<10 \mu \mathrm{m}$ size fraction

\begin{tabular}{|c|c|c|c|c|c|}
\hline Stn & $\mathrm{NH}_{4}^{+}$ & $\mathrm{NO}_{3}^{-}$ & Urea N & Glutamate C & Glutamate $\mathrm{N}$ \\
\hline \multicolumn{6}{|c|}{ May 2000} \\
\hline 9A & 40 & 15 & 32 & & 49 \\
\hline 18 & 67 & 100 & 61 & & 92 \\
\hline 27 & 94 & 100 & 94 & & 97 \\
\hline \multicolumn{6}{|c|}{ August 2000} \\
\hline 7 & 95 & 100 & 72 & 61 & 100 \\
\hline 9A & 96 & 53 & 56 & & 85 \\
\hline 18 & 82 & 100 & 88 & 68 & 67 \\
\hline 27 & 100 & 44 & 80 & 63 & 43 \\
\hline
\end{tabular}

Table 5. Concentrations of $\mathrm{NH}_{4}{ }^{+}$and DFAA, and mean (with standard deviation in parentheses) amino acid oxidation (AAO) rates and ${ }^{15} \mathrm{NH}_{4}{ }^{+}$uptake from ${ }^{15} \mathrm{~N}$-LYA-lysine in whole water samples collected along a river transect (August 1999)

\begin{tabular}{|cccccc|}
\hline Stn & $\begin{array}{c}{\left[\mathrm{NH}_{4}^{+}\right]} \\
(\mu \mathrm{M})\end{array}$ & $\begin{array}{c}\mathrm{DFAA}] \\
(\mu \mathrm{M})\end{array}$ & $\begin{array}{c}\mathrm{AAO} \\
\left(\mu \mathrm{M} \mathrm{d}^{-1}\right)\end{array}$ & $\begin{array}{c}{ }^{15} \mathrm{NH}_{4}{ }^{+} \text {uptake } \\
\left(\mu \mathrm{M} \mathrm{d}^{-1}\right)\end{array}$ & $\begin{array}{c}\% \\
\text { contribution } \\
\text { of AAO }\end{array}$ \\
\hline 1 & 2.49 & 0.18 & $0.14(0.006)$ & $4.07(1.07)$ & 3.5 \\
$9 \mathrm{~A}$ & 0.48 & 0.54 & $0.15(0.005)$ & $3.85(0.43)$ & 4.0 \\
18 & 6.29 & 0.17 & $0.07(0.002)$ & $1.97(0.21)$ & 3.4 \\
27 & 2.9 & 0.08 & $0.05(0.006)$ & $1.78(0.34)$ & 2.5 \\
& & & & & \\
\hline
\end{tabular}

stations, they were a much more important source of $\mathrm{N}$ than other inorganic and organic $\mathrm{N}$ compounds upriver (Fig. 4). Amino acid uptake correlated well with both AAO $\left(R^{2}=0.85\right)$ and $\mathrm{PH}\left(\mathrm{R}^{2}=0.89\right)$.

Most of the uptake of all $\mathrm{N}$ compounds tested could be attributed to the $<10 \mu \mathrm{m}$ size-fraction (small phytoplankton and bacteria) rather than to larger cells (Table 4). A notable exception was in May at Stn 9A, the turbidity maximum, when most of the uptake was by larger cells or aggregates in the $>10 \mu \mathrm{m}$ sizefraction.

Rates of $\mathrm{NH}_{4}{ }^{+}$uptake and $\mathrm{AAO}$ were compared in August 1999. Rates of $\mathrm{NH}_{4}{ }^{+}$uptake far exceeded rates of AAO at every station (Table 5), and there was no correlation between them. AAO provided only 2.5 to $4.0 \%$ of the $\mathrm{NH}_{4}{ }^{+}$that was taken up.

Rates of PH were up to $13 \%$ of the rates of total N uptake over the salinity gradient; however, we did not measure uptake of dipeptides, a likely product of $\mathrm{PH}$ in this study. Turnover times of DFAA and DCAA pools from $\mathrm{AAO}$ and $\mathrm{PH}$, respectively, were on the order of hours to days (Table 2). Both processes appeared to contribute more substantially to PON turnover than to POC turnover.

\section{C uptake rates}

Because standard terminology for C uptake differs between the stable and radioisotope literature, here we define the amount of label measured in filtered particulate matter as net uptake; this would be called incorporation in the ${ }^{14} \mathrm{C}$-uptake literature. We define gross $\mathrm{C}$ uptake as the sum of net $\mathrm{C}$ uptake and respiration (production of $\mathrm{CO}_{2}$ ).

Net and gross $\mathrm{C}$ uptake from amino acids were measured directly or estimated during August 1999 and in both months in 2000 (Table 6). Net amino acid C uptake and respiration by the $>0.2 \mu \mathrm{m}$ (Nuclepore filter) sizefraction were directly measured in August 1999 using ${ }^{14} \mathrm{C}$-labeled glutamic acid (Table 6). Gross uptake was 
Table 6. Net amino acid $\mathrm{C}$ and $\mathrm{N}$ uptake and respiration rates (measured using ${ }^{14} \mathrm{C}$ - [in 1999$],{ }^{13} \mathrm{C}$ - [in 2000$]$ and ${ }^{15} \mathrm{~N}$-labeled glutamic acid; SD in parentheses), $\mathrm{N}$ uptake and $\mathrm{C}$ release from amino acid oxidation (AAO), and gross amino acid $\mathrm{C}$ uptake (calculated as the sum of net $\mathrm{C}$ uptake and respiration). Data are for whole water incubations collected onto $0.2 \mathrm{and} 0.7 \mu \mathrm{m}$ (GF/F) filters in August 1999 and May/August 2000, respectively. C:N ratio of 3.7 for the DFAA pool was used to convert between C and $\mathrm{N}$ rates. Bold indicates estimated data. nd: not determined

\begin{tabular}{|c|c|c|c|c|c|c|}
\hline \multirow{2}{*}{ Stn } & \multicolumn{3}{|c|}{$\longrightarrow$ Glutamic acid $\longrightarrow$} & \multicolumn{2}{|c|}{$-\mathrm{AAO}=$} & \multirow[b]{2}{*}{$\begin{array}{c}\text { Gross C uptake } \\
\text { from DFAA } \\
\left(\mathrm{nM} \mathrm{C} \mathrm{h}^{-1}\right)\end{array}$} \\
\hline & $\begin{array}{l}\text { Net } \mathrm{C} \text { uptake } \\
\text { as DFAA } \\
\left(\mathrm{nM} \mathrm{C} \mathrm{h}^{-1}\right)\end{array}$ & $\begin{array}{l}\text { Net } \mathrm{N} \text { uptake } \\
\text { as DFAA } \\
\left(\mathrm{nM} \mathrm{N} \mathrm{h}^{-1}\right)\end{array}$ & $\begin{array}{l}\text { Respiration } \\
\left(\mathrm{nM} \mathrm{C} \mathrm{h}^{-1}\right)\end{array}$ & $\begin{array}{c}\text { N uptake } \\
\text { from AAO } \\
\left(\mathrm{nM} \mathrm{N} \mathrm{h}^{-1}\right)\end{array}$ & $\begin{array}{l}\text { C release } \\
\text { from AAO } \\
\left(n M \mathrm{C} \mathrm{h}^{-1}\right)\end{array}$ & \\
\hline \multicolumn{7}{|c|}{ August 1999: ${ }^{14} \mathrm{C}$ glutamate $(0.2 \mu \mathrm{m}$ filters $)$} \\
\hline 1 & $189(11)$ & $61.8^{\mathrm{a}}$ & $39.8(8)$ & 5.83 & 21.6 & 228.8 \\
\hline $9 \mathrm{~A}$ & $568(31)$ & $189.6^{\mathrm{a}}$ & $133.4(1.2)$ & 12.1 & 44.7 & 701.4 \\
\hline 18 & 133 (13) & $54.9^{a}$ & $70.2(10)$ & 2.50 & 9.25 & 203.2 \\
\hline 25 & $27(2)$ & $10.6^{\mathrm{a}}$ & $12.2(0.9)$ & 0.42 & 1.54 & 39.2 \\
\hline \multicolumn{7}{|c|}{ May 2000: ${ }^{15} \mathrm{~N}$ glutamate (GF/F filters) } \\
\hline 5 & nd & 148.9 (nd) & & 56.2 & 207.9 & $550.9^{\mathrm{b}}$ \\
\hline $9 \mathrm{~A}$ & nd & $453.9(11)$ & & 81.7 & 302.2 & $1679.4^{\mathrm{b}}$ \\
\hline 18 & nd & $70.4(7.2)$ & & 3.09 & 11.4 & $260.5^{\mathrm{b}}$ \\
\hline 27 & nd & $27.8(1.7)$ & & 0.00 & 0.0 & $102.9^{b}$ \\
\hline \multicolumn{7}{|c|}{ August 2000: ${ }^{13} \mathrm{C},{ }^{15} \mathrm{~N}$ glutamate (GF/F filters) } \\
\hline 7 & $158.0(43)$ & $61(7.5)$ & 58.3 & 2.55 & 9.42 & $225.7^{\mathrm{b}}$ \\
\hline $9 \mathrm{~A}$ & $0(16)$ & $26.3(1.5)$ & 90.8 & 1.77 & 6.55 & $97.3^{b}$ \\
\hline 18 & $82.6(9.5)$ & $44.1(3.7)$ & 77.0 & 0.96 & 3.56 & $163.2^{\mathrm{b}}$ \\
\hline 27 & $106.6(12.4)$ & $62.1(1.5)$ & 104.8 & 4.98 & 18.4 & $229.8^{\mathrm{b}}$ \\
\hline
\end{tabular}

then calculated as the sum of net uptake plus respiration. Respiration rates ranged from 17 to $35 \%$ of gross C uptake. A smaller proportion of gross C uptake was respired at stations with higher salinities. DFAA-N uptake rates were calculated from gross C-uptake rates using the C:N of the DFAA pool. There was no clear trend of estimated gross C-uptake rate with salinity; rates were highest at Stn 9A and lowest at the least-saline station.

In May 2000, gross DFAA-C-uptake by the $>0.7 \mu \mathrm{m}$ size-fraction (GF/F filter) was estimated from ${ }^{15} \mathrm{~N}-\mathrm{la}-$ beled glutamic acid-uptake rates (Table 6). Assuming that no ${ }^{15} \mathrm{~N}$ taken up was re-released into the water (i.e., net $\mathrm{N}$ uptake $=$ gross $\mathrm{N}$ uptake), the measured ${ }^{15} \mathrm{~N}$ uptake rates were multiplied by the $\mathrm{C}: \mathrm{N}$ ratio of the DFAA pool to obtain gross C uptake. As in 1999, rates were highest at Stn 9A and lowest at the least-saline station.

Net amino acid $\mathrm{C}$ and $\mathrm{N}$ uptake by the $>0.7 \mu \mathrm{m}$ sizefraction were directly measured in August 2000 using dually labeled $\left({ }^{13} \mathrm{C}\right.$ and $\left.{ }^{15} \mathrm{~N}\right)$ glutamic acid (Table 6). Again, gross $\mathrm{C}$-uptake rates were estimated from $\mathrm{N}$ uptake measurements as described above. Dual labels enabled us to determine the $\mathrm{C}: \mathrm{N}$ ratios of amino acid uptake, and these ranged from 0 at Stn 9A, to 2.6 at Stn 7 (Fig. 5). The difference between the estimated gross C-uptake rate and the measured net C-uptake rate was assumed to be due to respiration. Thus, the percent of gross uptake that was respired by the $>0.7 \mu \mathrm{m}$ size-fraction ranged from 26 to $93 \%$; this was much higher than in August 1999 for the >0.2 $\mu \mathrm{m}$ sizefraction. There was no apparent trend in gross C uptake with salinity; uptake was lowest at Stn 9A, in contrast to the other months measured.

Several factors may have affected our uptake estimates. Because of the differences in filter pore size among experiments using radio- versus stable isotopes, it is likely that bacterial $\mathrm{C}$ uptake was underestimated in the stable isotope experiments (which used $\mathrm{GF} / \mathrm{F}$ filters with a nominal pore size of $0.7 \mu \mathrm{m})$. In the

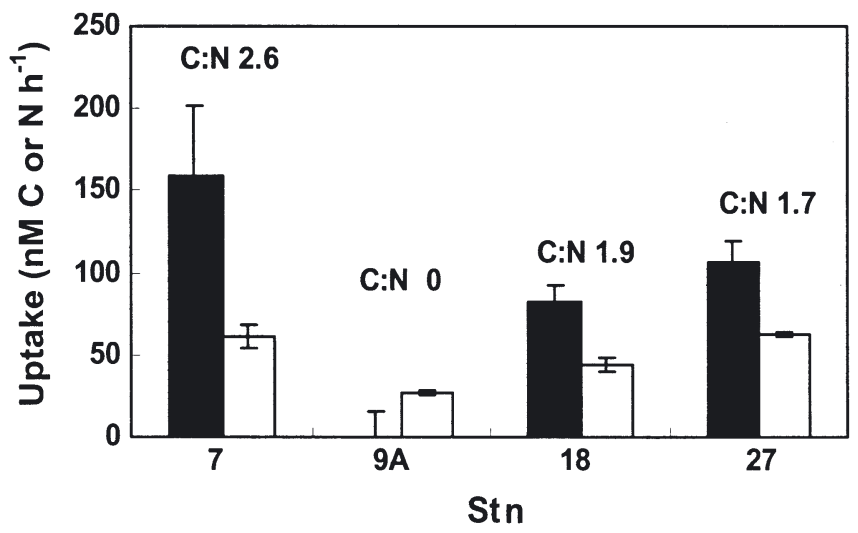

Fig. 5. Rates of amino acid uptake in August 2000. Dually labeled $\left({ }^{13} \mathrm{C}\right.$ and $\left.{ }^{15} \mathrm{~N}\right)$ glutamatic acid was used to estimate net uptake of $\mathrm{C}$ (black bars) and $\mathrm{N}$ (white bars) by the sizefraction collected on GF/F filters (nominal pore size: $0.7 \mu \mathrm{m}$ ) 


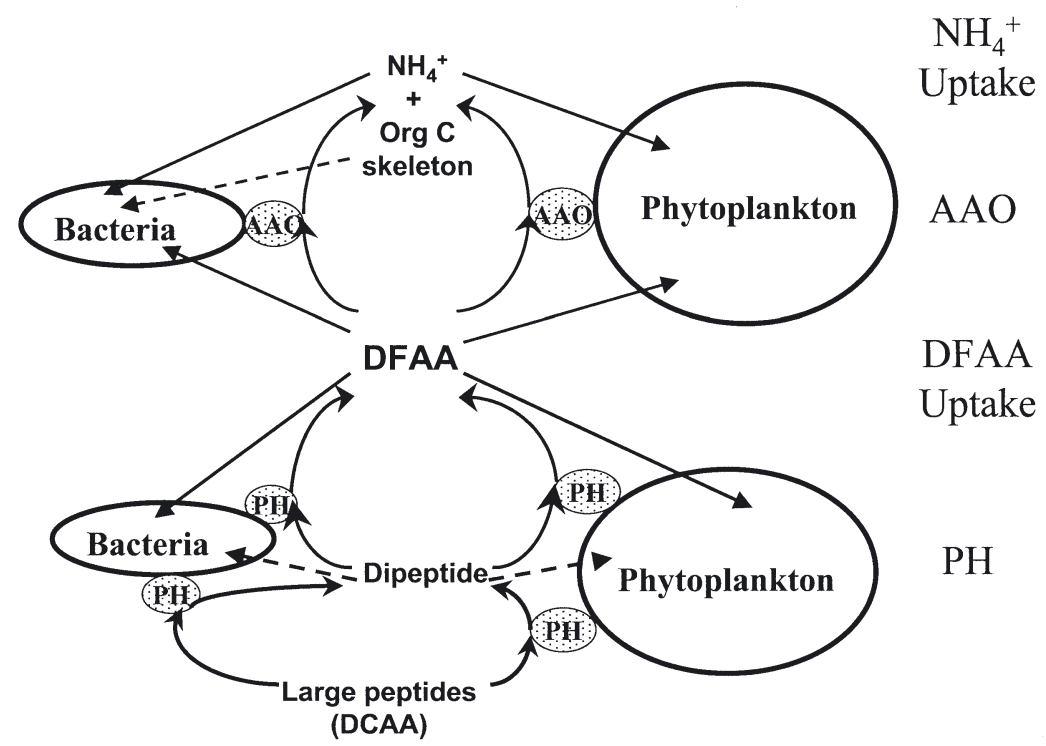

Fig. 6. Conceptual model showing relationships between extracellular amino acid oxidation (AAO), peptide hydrolysis ( $\mathrm{PH}), \mathrm{NH}_{4}{ }^{+}$uptake, and dissolved free amino acid (DFAA), uptake and cycling. Broken arrows = pathways not measured during this study

calculations of $\mathrm{C}$ uptake (Table 6), net $\mathrm{N}$-uptake rates were not corrected for the uptake of $\mathrm{NH}_{4}{ }^{+}$released from amino acids during extracellular AAO. If all of the $\mathrm{NH}_{4}{ }^{+}$released from AAO were taken up, this correction would have resulted in lower net $\mathrm{N}$-uptake rates from DFAA and lower estimates of gross C uptake in May and August 2000 by the amount shown in Table 6 . Similarly, gross or net $\mathrm{C}$ uptake rates were not corrected for the uptake of $\mathrm{C}$ compounds released during extracellular AAO. If $\mathrm{C}$ compounds released from AAO were taken up, gross C-uptake from DFAA would be overestimated by the amount shown in Table 6 .

\section{DISCUSSION}

Amino acids are important cellular components that play a major role in microbial metabolism. Thus, con- centrations and turnover of DFAA and DCAA in estuarine and marine systems have been relatively well studied compared to many other nitrogen-containing DOM compound classes. The concentrations of DFAA measured in this study are consistent with those in other studies, e.g. 0.18 to $0.22 \mu \mathrm{M}$ DFAA in Flax Pond, New York (Jørgensen et al. 1993), 0.3 to $0.7 \mu \mathrm{M}$ in the Delaware Estuary (Middelbøe et al. 1995), and 0.14 to $0.47 \mu \mathrm{M}$ in the mesohaline Chesapeake Bay (Bronk et al. 1998). Concentrations of DCAA are also consistent with those in studies of other estuarine systems (Keil \& Kirchman 1991, 1999).

Extracellular AAO and $\mathrm{PH}$ are pathways whereby dissolved amino acid pools can be mobilized to provide nutrients (e.g. C and N) for estuarine autotrophs and heterotrophs. Fig. 6 shows a conceptual model of the various interacting pathways. While DOM has usually been thought to support primarily heterotrophic nutrition in nature, recent field evidence has linked DON with phytoplankton nutrition, in particular that of bloom-forming mixotrophic plankton (Paerl 1988, Berg et al. 1997, Glibert et al. 2001). A variety of species can use DON to meet their N needs (Antia et al. 1991), and heterotrophic uptake of dissolved organic C (DOC) (Lewitus \& Caron 1991) including DFAA (Wheeler et al. 1977) has been observed in a number of phytoplankton taxa. Consequently, in our model, we do not attribute uptake or mobilization of DFAA and DCAA strictly to bacteria (Fig. 6).

\section{N uptake}

While uptake of $\mathrm{NH}_{4}{ }^{+}$was the dominant pathway of $\mathrm{N}$ uptake in our study, particularly at higher-salinity stations, $\mathrm{NO}_{3}^{-}$uptake was important at lower-salinity stations where $\mathrm{NO}_{3}{ }^{-}$concentrations were high (Fig. 4). Urea and DFAA were also significant sources of N (Fig. 4).

Table 7. Literature values for dissolved free amino acid (DFAA) uptake rates from other estuaries

\begin{tabular}{|c|c|c|c|c|}
\hline Site & $\begin{array}{l}\text { DFAA uptake } \\
\quad\left(\mathrm{nM} \mathrm{h}^{-1}\right)\end{array}$ & $\begin{array}{l}\text { DFAA uptake as \% } \\
\text { total N uptake }\end{array}$ & Method & Source \\
\hline Chesapeake Bay plume & $1.0-92.5$ & $1-7$ & ${ }^{15} \mathrm{~N}$ & Glibert et al. (1991) \\
\hline Shinnecock Bay, Long Island & $0.6-7.1$ & $11-16$ & ${ }^{15} \mathrm{~N}$ & Berg et al. (1997) \\
\hline Long Island Sound & $3.8-35.3$ & & ${ }^{3} \mathrm{H}$ & Fuhrman (1987) \\
\hline Flax Pond, NY & 73.7 & & ${ }^{14} \mathrm{C}$ & Jørgensen et al. (1993) \\
\hline Thames River estuary & $6-150$ & $3-93$ & ${ }^{15} \mathrm{~N}$ & Middelburg \& Nieuwenhuize (2000) \\
\hline Chesapeake Bay & $252-376$ & Up to 55 & ${ }^{15} \mathrm{~N}$ & Bronk \& Glibert $(1993)^{\mathrm{a}}$ \\
\hline
\end{tabular}


Urea can contribute more than $50 \%$ of the total $\mathrm{N}$ uptake by phytoplankton in some estuarine systems (Glibert et al. 1991, Berg et al. 1997); however, the rates observed in this study were always less than $18 \%$ of the total $\mathrm{N}$ uptake. The rates of DFAA-N uptake and DFAA contribution to total N uptake in the Pocomoke River estuary are consistent with those in a variety of other estuarine studies (Table 7).

\section{Extracellular enzymatic activity}

Methodological issues. The rates of amino acid uptake, AAO and $\mathrm{PH}$ reported here must be considered maximum potential rates for 2 reasons: First, for $\mathrm{AAO}$ and $\mathrm{PH}$, rate constants determined on samples transported to the laboratory were higher than those determined immediately after collection (Table 3); second, calculations assumed that $100 \%$ of the DFAA and DCAA pools were available, and this is unlikely in nature. Other factors can also affect $\mathrm{PH}$ rate calculations. For example, LYA-ala4 is unlikely to be a perfect analog of available peptides; the composition and length of naturally occurring peptide and protein chains are unknown. Previous studies indicate that the length and composition of the peptide chain can affect the rate of hydrolysis (Pantoja et al. 1997, Pantoja \& Lee 1999). Finally, no dilution effects were considered for any of the enzyme rate calculations, although additions were usually $<10 \%$ of the ambient pools and so could be considered tracer-level additions.

The LYA peptide analogs used in this study allow the direct measurement of $\mathrm{PH}$ products. The methods used in this study differ from some other approaches used to assess cell-surface enzyme activity. Commercially available dipeptide-like substrates, such as L-leucine 7-amido-4-methyl-coumarin (leu-MCA), have been used to assess leucine aminopeptidase activity (e.g. Rosso \& Azam 1987, Crottereau \& Delmas 1998, Stoecker \& Gustafson 2003). In this study of the Pocomoke River, LYA-dipeptides were the primary products of hydrolysis; further hydrolysis of dipeptides to free amino acids was very slow. This observation is similar to those from previous studies (Pantoja et al. 1997, Pantoja \& Lee 1999, Mulholland et al. 2002). Pantoja \& Lee (1999) found that LYA-peptides containing $>2$ amino acids were hydrolyzed 10 to 400 times faster than dipeptides or the fluorogenic substrate leu-MCA. One possible explanation for slower dipeptide hydrolysis is steric hindrance of hydrolysis by the presence of the large fluorescent derivative; however, Pantoja \& Lee (1999) showed that this is unlikely. Alternatively, dipeptides may be small enough (e.g. <600 Da) to be incorporated directly by microorganisms, so that induction of enzymes to hydrolyze dipeptides is not necessary. Thus, use of dipeptide analogs or leu-MCA may result in an underestimate of $\mathrm{PH}$ rates.

Amino acid oxidation. The first-order rate constants for AAO reported here were up to 1 order of magnitude lower than those observed in Shinnecock Bay, Long Island (Mulholland et al. 1998), and comparable to those observed during a brown-tide (Aureococcus anophagefferens) bloom in Quantuck Bay, another Long Island embayment (Mulholland et al. 2002), when temperatures were comparable. The potential contribution of AAO to $\mathrm{NH}_{4}{ }^{+}$uptake over the salinity gradient was $<5 \%$ during the 2000 surveys (Table 5), suggesting that AAO was not a significant source of $\mathrm{NH}_{4}{ }^{+}$for bulk $\mathrm{NH}_{4}{ }^{+}$uptake. However, depending on the community structure, AAO could be an important source of nutrition to particular organisms. Bacteria and a variety of phytoplankton species are capable of AAO (Palenik \& Morel 1990a, 1991, Pantoja \& Lee 1994, Mulholland et al. 1998), and rates of extracellular oxidation of amino acids vary among marine environments (Pantoja \& Lee 1994, Mulholland et al. 1998, Mulholland et al. unpubl. data). Higher rates have been observed in coastal environments where productivity is high and inorganic $\mathrm{N}$ concentrations are low (Mulholland et al. 1998). It is likely that the availability of organic nutrients and/or inorganic $\mathrm{N}$ influence the rates of $\mathrm{C}$ and $\mathrm{N}$ regeneration by this pathway. However, the environmental or nutritional conditions and the importance of community structure in promoting extracellular AAO activity by microbes and phytoplankton are unknown.

Peptide hydrolysis. The rates of $\mathrm{PH}$ measured in the Pocomoke River varied by 1 order of magnitude among study periods (Table 2). The higher rate constants measured in 1999 were comparable to those measured in Quantuck Bay during a brown tide bloom (Mulholland et al. 2002). In 2000, PH rates in the Pocomoke River were lower, comparable to those observed during the colder months in Quantuck Bay (Mulholland et al. 2002). However, rate constants for $\mathrm{PH}$ in the Pocomoke River were comparable to those reported from Flax Pond, a salt marsh in New York (Pantoja \& Lee 1999). The rates of $\mathrm{PH}$ measured in this study exceeded by 1 order of magnitude those reported for brackishwater in Kiel Fjord using leu-MCA (Hoppe et al. 1993). This may be due to either lower rates of hydrolysis of dipeptides (see earlier subsection 'Methodological issues') or to real differences in productivity among the environments sampled.

The relative contributions of phytoplankton and bacteria to AAO and PH could not be estimated directly in our study. Similar to our previous studies, no enzymatic activity was observed in the $<0.2 \mu \mathrm{m}$ size-fractions, indicating that proteolytic enzymes were not present in the free state or in association with very small cells. 
Instead, both $\mathrm{AAO}$ and $\mathrm{PH}$ were associated primarily with particulate matter, the $>1.0$ or $>1.2 \mu \mathrm{m}$ sizefractions in this study. Because bacteria are thought to be the main consumers and degraders of organic material in marine systems, it has been generally assumed that PH is associated with free-living or attached bacteria in marine environments (Chróst 1991, Hoppe 1991). Correlations between rates of $\mathrm{PH}$, and estimates of enzymatic PON and bacterial biomass turnover have been used to support the idea that bacterial productivity is closely coupled with degradation of PON in the North Atlantic Ocean (Hoppe et al. 1993). Substantially greater proteolytic activity was also found in association with bacteria attached to sinking aggregates (Smith et al. 1992). However, most existing measurements of $\mathrm{PH}$ are attributed to bacterial processes even when bacterial biomass and productivity are not correlated with PH (e.g. Hoppe 1991). The results reported here suggest that either cells other than bacteria are capable of $\mathrm{PH}$, or that there is significant $\mathrm{PH}$ by bacteria attached to particles and bacterial aggregates larger than $1.2 \mu \mathrm{m}$.

The role of planktonic organisms in the hydrolysis of peptides has not been extensively examined. Proteolytic activity has been found in association with cyanobacteria (Martinez \& Azam 1993) and marine phytoplankton (Berges \& Falkowski 1996), but there has been little work to quantify its importance to the nutrition of these organisms. Using LYA-analogs, high rates of extracellular PH have been observed by natural and cultured populations of phytoplankton mixotrophs, i.e. the dinoflagellate Pfiesteria piscicida (M. Mulholland et al. unpubl. data), and the pelagophyte Aureococcus anophagefferens (Mulholland et al. 2002). Using leu-MCA, proteolytic activity was also found in axenic cultures of the dinoflagellates Alexandrium tamarense, Heterocapsa triquetra and Prorocentrum minimum, as well as for non-axenic cultures of Akashio tamarense, Gonyaulax grindleyi, Gyrodinium uncatenum and Karlodinium micrum (Stoecker \& Gustafson 2003). Similarly, in a mixed bloom of dinoflagellates in the Chesapeake Bay, total leucine aminopeptidase activity was positively correlated with dinoflagellate abundance (Stoecker \& Gustafson 2003). Other phytoplankton species and groups produce extracellular enzymes such as amino acid oxidases (Palenik \& Morel 1990a, 1991, Mulholland et al. 1998) and alkaline phosphatases (Ammerman 1991), and thus might also be able to produce hydrolases.

Dissolved proteins and peptides have the potential to alleviate $\mathrm{N}$ limitation for organisms that can break down and use these as growth substrates. Estuarine bacteria may use a variety of organic compounds, including those containing little $\mathrm{N}$, to acquire $\mathrm{C}$ for growth (Arnosti et al. 2000). Sala et al. (2001) used amino peptidase activity as an indicator of $\mathrm{N}$ deficiency in an estuarine microbial community. They found an inverse correlation between DIN concentration and PH. However, in our study, DIN concentrations were always measurable even at the higher salinity stations, and there was no correlation between DIN and $\mathrm{PH}$. Alone, rates of AAO in the Pocomoke River were not high enough to support typical organismal growth rates.

The correlation between amino acid and PH uptake in this study $\left(R^{2}=0.89\right)$ suggests that the degradation of DFAA and DCAA uptake are coupled. However, we did not observe significant production of free amino acids from $\mathrm{PH}$, and these and previous observations using LYA-ala4 indicate that the primary products of $\mathrm{PH}$ are dipeptides rather than DFAA. If the failure to produce DFAA from DCAA is a methodological artifact (see earlier subsection 'Methodological issues') and DFAAs are a significant product of $\mathrm{PH}$, rates of $\mathrm{PH}$ may have been sufficient to produce a large portion of the amino acids that were taken up or oxidized (Table 2). In a study of the sea-surface microlayer and the seawater directly beneath it, added protein was consumed without a subsequent increase in concentration or change in the composition of the DFAA pool (Kuznetsova \& Lee 2002). This suggests that there is tight coupling between DCAA hydrolysis and uptake of hydrolysis products.

Salinity may be an important direct or indirect control on PH. Although there was no clear correlation between PH and salinity in the Pocomoke River, rates of PH were lowest at the lowest-salinity station. Stepanauskas et al. (1999) found that additions of terrestrially derived DOM isolated from 3 wetlands resulted in higher proteolytic enzyme activity in bacteria grown on saltwater versus freshwater medium. These investigators concluded that this natural DON was more than 2 times more bioavailable in seawater than in freshwater, suggesting that marine bacterioplankton are better adapted for using DON substrates. However, in the Pocomoke River system, chl a biomass also generally varied with salinity, so $\mathrm{PH}$ activity might as easily be related to chl $a$ as to salinity, although our correlations were weak. Stn 9A, located near the estuarine turbidity maximum, always had the highest chl a levels and the highest $\mathrm{PH}$ rates.

DFAA and DCAA turnover. Based on our calculations, turnover times for the DFAA pool due to AAO ranged from $5 \mathrm{~h}$ in May 1999 to $247 \mathrm{~h}$ in August 2000 (Table 2), times that are insufficient to support typical organismal growth rates. Similarly, the turnover time for the DCAA pool due to $\mathrm{PH}$ ranged from 4.7 to $150 \mathrm{~h}$. When DFAA uptake was factored in, average DFAA turnover times were on the order of 1.6 to $9.9 \mathrm{~h}(0.07$ to $0.41 \mathrm{~d})$, i.e. on the order of those observed in other estuarine areas. For compari- 
son, in the Mississippi River plume, DFAA turnover times increased with increasing salinity and ranged from 0.02 to $0.14 \mathrm{~d}$ in the summer and 0.013 to 0.073 $\mathrm{d}$ in the winter using ${ }^{3} \mathrm{H}$-DFAA (Hopkinson et al. 1998). In the mesohaline Chesapeake Bay, DON turnover times ranged from 0.27 to $2.53 \mathrm{~d}$ using ${ }^{15} \mathrm{~N}$ tracer techniques (Bronk et al. 1998). In the Choptank River, another subestuary of the Chesapeake Bay, low molecular weight DON had shorter turnover times $(15.9$ d) than high molecular weight DON (33.8 di Bronk \& Glibert 1993). In the Chesapeake Bay plume, Fuhrman (1990) measured very rapid turnover times using ${ }^{3} \mathrm{H}$-DFAA.

\section{$\mathrm{C}-\mathrm{N}$ coupling}

Previous studies have employed a variety of isotopic methods to measure DFAA uptake and turnover; radiolabeled amino acids $\left({ }^{14} \mathrm{C}\right.$ and $\left.{ }^{3} \mathrm{H}\right)$ are commonly used to measure heterotrophic DFAA-C uptake and turnover by bacteria, while ${ }^{15} \mathrm{~N}$-labeled amino acids are used frequently to measure DFAA-N uptake by phytoplankton. An important methodological issue between the radioisotope and stable isotope techniques is the issue of filtration and filter-pore sizes. Uptake of ${ }^{14} \mathrm{C}$ - and ${ }^{3} \mathrm{H}$ labeled DFAA are usually measured after filtration onto $0.2 \mu \mathrm{m}$ membrane filters, and uptake is attributed to bacterial heterotrophs. Uptake of ${ }^{15} \mathrm{~N}$-labeled DFAA and other $\mathrm{N}$ substrates are measured after filtration onto GF/F filters (compatible with combustion techniques) with nominal pore sizes of $0.7 \mu \mathrm{m}$, and uptake is attributed to phytoplankton autotrophs. To avoid this problem and still simultaneously determine the relative contribution of amino acids to $\mathrm{C}$ and $\mathrm{N}$ nutrition, we used dual-labeled compounds $\left({ }^{13} \mathrm{C}\right.$ and $\left.{ }^{15} \mathrm{~N}\right)$ during the August 2000 study period and related uptake of $\mathrm{C}$ and $\mathrm{N}$ to previous measurements made using either ${ }^{14} \mathrm{C}$ or ${ }^{15} \mathrm{~N}$-labeled substrates.

In uptake experiments in August 1999, DFAA were significant sources of $\mathrm{C}$ to organisms $>0.2 \mu \mathrm{m}$ (Table 6). In August 2000, when dual-labeled amino acids were used to trace net $\mathrm{C}$ and $\mathrm{N}$ uptake by larger cells (e.g. $>0.7 \mu \mathrm{m})$, net $\mathrm{C}$ uptake from amino acids into these larger cells varied among river stations (Table 6), and the observed net C:N uptake ratio varied from 0 to 2.6 (Fig. 5). This substantial variation in C uptake (0 to $52 \%$ of the total available amino acid C) suggests that DFAA may serve as either a $\mathrm{C}$ or $\mathrm{N}$ substrate for growth, or both. For example, little amino acid C was used at Stn 9A in August 2000, indicating that DFAA were primarily an $\mathrm{N}$ source for growth for cells larger than $0.7 \mu \mathrm{m}$ at this station. We did not determine which organisms were responsible for $\mathrm{C}$ and $\mathrm{N}$ uptake.
Differences in respiration rates may account for some of the variability in $\mathrm{C}$ versus $\mathrm{N}$ uptake. However, competition for amino acid $\mathrm{C}$ and $\mathrm{N}$ between bacteria and phytoplankton mixotrophs in environments depleted in inorganic $\mathrm{N}$ may also be important. Higher rates of net $\mathrm{C}$ uptake and a lower proportion of respiration (17 and $19 \%$ of gross uptake) were observed in the 2 saltier river stations compared to the 2 freshwater stations (31 and $34.5 \%$ of gross uptake respired) measured in 1999 (Table 6). This is generally consistent with the lower $\mathrm{C}: \mathrm{N}$ incorporation ratios (1.7 to 1.9 ) observed at the freshwater stations, where DIN concentrations were much higher in 2000, and the higher C:N incorporation rates at the saltiest station, where DIN concentrations were low. However, at Stn 9A, high net C-uptake rates in 1999 are in marked contrast to the absence of significant net $\mathrm{C}$ uptake from DFAA in 2000. This contrast may be due to differences in the nutrient environment at this station between years or may reflect a higher bacterial contribution to organic $\mathrm{C}$ uptake at this station (different size-fractions were measured in the two years). Net uptake of $\mathrm{C}$ and $\mathrm{N}$ from amino acids needs to be more carefully examined to explain the relative uptake of these elements by competing microorganisms. Further examination of species-specific capabilities and nutrient controls on extracellular enzyme activity and the relative uptake of $\mathrm{C}$ versus $\mathrm{N}$ from DOM are needed, particularly in organically enriched environments where mixotrophy is common.

\section{Summary}

Amino acid oxidation and peptide hydrolysis are pathways of organic matter degradation in the Pocomoke River system, a mid-Atlantic subestuary of the Chesapeake Bay. In the Pocomoke River, the contribution of AAO to the total N nutrition and to DFAA turnover was small, but the importance of this pathway to individual organisms that are capable of AAO was not assessed. While PH has been widely attributed to bacteria, larger organisms, including phytoplankton mixotrophs may be capable of hydrolyzing peptides at high rates in estuarine systems. However, the nutritional importance of $\mathrm{PH}$ to these organisms has not been widely examined. Uptake of organic compounds contributed to the $\mathrm{C}$ and $\mathrm{N}$ nutrition of estuarine organisms in this system, including those in the sizefraction typically used to assess phytoplankton processes. Uptake of $\mathrm{C}$ and $\mathrm{N}$ from amino acid substrates was uncoupled; uncoupling can result from competing extracellular and intracellular processes and from competition among auto- and heterotrophs. Organisms taking up organic substrates can use them for $\mathrm{N}$ or $\mathrm{C}$ nutrition or both. This may be important in determin- 
ing community structure and competitive outcomes among organisms that can use DOM substrates. The type of organic matter and the nature of competition for that organic matter might depend on whether competing organisms are C-limited, N-limited, or both, and whether the organisms are limited by either organic or inorganic N. Further, the assumptions used to evaluate degradative and assimilative processes based on the size-fraction caught on filters need to be reevaluated, because organic compounds can be used to support both auto- and heterotrophic nutrition.

Acknowledgements. We would like to thank J. Alexander, E. Haramoto and M. Trice for assisting during field efforts, and J. Hawkey for help with graphics. This work was supported by an NSF grant to $C$. Lee and a grant from the US ECOHAB Program to P.M.G. The ECOHAB Program is sponsored by the National Oceanic and Atmospheric Administration, Environmental Protection Agency, National Science Foundation, National Aeronautics and Space Administration, and Office of Naval Research. This is contribution \#1262 from SUNY Stony Brook, \#3679 from the University of Maryland Center for Enviromental Science, and \#F4 from the US ECOHAB Program.

\section{LITERATURE CITED}

Ammerman JW (1991) Role of ecto-phosphohydrolases in phosphorus regeneration in estuarine and coastal ecosystems. In: Chróst RJ (ed) Microbial enzymes in aquatic environments. Springer-Verlag, New York, p 165-186

Antia NJ, Harrison PJ, Oliveira L (1991) The role of dissolved organic nitrogen in phytoplankton nutrition, cell biology and ecology. Phycologia 30:1-89

Arnosti C, Keith SC, Blough NV (2000) Application of fluorescence spectroscopic techniques and probes to the detection of biopolymer degradation in natural environments. Mar Chem 71:321-330

Berg GM, Glibert PM, Lomas MW, Burford M (1997) Organic nitrogen uptake and growth by the chrysophyte Aureococcus anophagefferens during a brown tide event. Mar Biol 129:377-387

Berges JA, Falkowski PG (1996) Cell-associated proteolytic enzymes from marine phytoplankton. J Phycol 32:566-574

Bronk DA (2002) Dynamics of DON. In: Carlson C, Hansell D (eds) Biogeochemistry of marine dissolved organic matter. Academic Press, San Diego, p 153-247

Bronk DA, Glibert PM (1993) Contrasting patterns of dissolved organic nitrogen release by two size-fractions of estuarine plankton during a period of rapid $\mathrm{NH}_{4}{ }^{+}$consumption and $\mathrm{NO}_{2}^{-}$production. Mar Ecol Prog Ser 96: 291-299

Bronk DA, Glibert PM, Malone TC, Banahan S, Sahlsten E (1998) Inorganic and organic nitrogen cycling in Chesapeake Bay: autotrophic versus heterotrophic processes and relationships to carbon flux. Aquat Microb Ecol 15: 177-189

Chróst RJ (1991) Environmental control of the synthesis and activity of aquatic microbial ectoenzymes. In: Chróst RJ (ed) Microbial enzymes in aquatic environments, Springer-Verlag, New York, p 29-59

Cowie GL, Hedges JI (1992) Improved amino acid quantifica- tion in environmental samples: charged-matched recovery standards and reduced analysis time. Mar Chem 37: 223-238

Crottereau C, Delmas D (1998) Exoproteolytic activity in an Atlantic pond (France): estimates of in situ activity. Aquat Microb Ecol 15:217-224

Dortch Q, Clayton JR Jr, Thoresen SS, Ahmed SI (1984) Species differences in accumulation of nitrogen pools in phytoplankton. Mar Biol 81:237-250

Fuhrman J (1987) Close coupling between release and uptake of dissolved free amino acids in seawater studied by an isotope dilution approach. Mar Ecol Prog Ser 37:45-52

Fuhrman J (1990) Dissolved free amino acid cycling in an estuarine outflow plume. Mar Ecol Prog Ser 66:197-203

Glibert PM, Capone DG (1993) Mineralization and assimilation in aquatic, sediment, and wetland systems. In: Knowles R, Blackburn TH (eds) Nitrogen isotope techniques. Academic Press, New York, p 243-272

Glibert PM, Garside C, Fuhrman JA, Roman MR (1991) Timedependent coupling of inorganic and organic nitrogen uptake and regeneration in the plume of the Chesapeake Bay estuary and its regulation by large heterotrophs. Limnol Oceanogr 24:683-696

Glibert PM, Magnien R, Lomas MW, Alexander J, Fan C, Haramoto E, Trice M, Kana TM (2001) Harmful algal blooms in the Chesapeake and coastal bays of Maryland, USA: comparison of 1997, 1998, and 1999 events. Estuaries 24:875-883

Gobler CJ, Sañudo-Wilhelmy SA (2001) Effects of organic carbon, organic nitrogen, inorganic nutrients, and iron additions on the growth of phytoplankton and bacteria during a brown tide bloom. Mar Ecol Prog Ser 219:19-34

Hansell DA, Carlson CA (2002) Biogeochemistry of marine dissolved organic matter. Academic Press, San Diego

Hedges JI, Keil RG, Benner R (1997) What happens to terrestrial organic matter in the ocean? Org Geochem 27:195-212

Hollibaugh JT, Azam F (1983) Microbial degradation of dissolved proteins in seawater. Limnol Oceanogr 28: $1104-1116$

Hopkinson C, Buffam I, Hobbie J, Vallino J and 11 others (1998) Terrestrial inputs of organic matter to coastal ecosystems: an intercomparison of chemical characteristics and bioavailability. Biogeochemistry 43:211-234

Hoppe HG (1983) Significance of exoenzymatic activities in the ecology of brackish water: measurements by means of methylumbelliferyl-substrates. Mar Ecol Prog Ser 11: 299-308

Hoppe HG (1991) Microbial extracellular enzyme activity: a new key parameter in aquatic ecology. In: Chróst RJ (ed) Microbial enzymes in aquatic environments. SpringerVerlag, New York, p 60-83

Hoppe HG, Ducklow H, Karrasch B (1993) Evidence for dependency of bacterial growth on enzymatic hydrolysis of particulate organic matter in the mesopelagic ocean. Mar Ecol Prog Ser 93:277-283

Jørgensen NOG, Kroer N, Coffin RB, Yang XH, Lee C (1993) Dissolved free amino acids, combined amino acids, and DNA as sources of carbon and nitrogen to marine bacteria. Mar Ecol Prog Ser 98:135-148

Keil RG, Kirchman DL (1991) Dissolved combined amino acids in marine waters as determined by a vapor-phase hydrolysis method. Mar Chem 33:243-259

Keil RG, Kirchman DL (1992) Bacterial hydrolysis of protein and methylated protein and its implications for studies of protein degradation in aquatic systems. Appl Environ Microbiol 58:1374-1375

Keil RG, Kirchman DL (1999) Utilization of dissolved protein 
and amino acids in the northern Sargasso Sea. Aquat Microb Ecol 18:293-300

Kirchman DL (2000) Uptake and regeneration of inorganic nutrients by marine heterotrophic bacteria. In: Kirchman DL (ed) Microbial ecology of the oceans. Wiley-Liss, New York, p 261-288

Kuznetsova M, Lee C (2002) Dissolved free and combined amino acids in nearshore seawater, sea surface microlayers and foams: influence of extracellular hydrolysis. Aquat Sci 64:1-17

Lee C (1992) Controls on organic carbon preservation: the use of stratified water bodies to compare intrinsic rates of decomposition in oxic and anoxic systems. Geochim Cosmochim Acta 56:3323-3335

Lee C, Cronin C (1984) Particulate amino acids in the sea: effects of primary productivity and biological decomposition. J Mar Res 42:1075-1097

Lewitus AJ, Caron DA (1991) Physiological responses of phytoflagellates to dissolved organic substrate additions. I. Dominant role of heterotrophic nutrition in Poterioochromonas malhamensis (Chrysophyceae). Plant Cell Physiol 32:671-680

Lewitus AJ, Kana TM (1994) Responses of estuarine phytoplankton to exogenous glucose: stimulation versus inhibition of photosynthesis and respiration. Limnol Oceanogr 39:182-188

Lewitus AJ, Willis BM, Hayes KC, Burkholder JM, Glasgow HB Jr, Glibert PM, Burke MK (1999) Mixotrophy and nitrogen uptake by Pfiesteria piscicida (Dinophyceae). J Phycol 35:1430-1437

Lindroth P, Mopper K (1979) High performance liquid chromatographic determination of subpicomole amounts of amino acids by precolumn fluorescence derivatization with o-phthaldialdehyde. Anal Chem 51:1667-1674

Martinez J, Azam F (1993) Aminopeptidase activity in marine chroococcoid cyanobacteria. Appl Environ Microbiol 59: 3701-3707

Maryland Department of Natural Resources (1998) Water quality, habitat and biological conditions of river systems affected by Pfiesteria or Pfiesteria-like organisms on the lower eastern shore of Maryland. 1997 Summary. Tidewater Ecosystem Assessment Division Report, Maryland Department of Natural Recources, Annapolis

Middelboe M, Borch NH, Kirchman DL (1995) Bacterial utilization of dissolved free amino acids, dissolved combined amino acids and ammonium in the Delaware Bay estuary: effects of carbon and nitrogen limitation. Mar Ecol Prog Ser 128:109-120

Middelburg JJ, Nieuwenhuize J (2000) Nitrogen uptake by heterotrophic bacteria and phytoplankton in the nitraterich Thames estuary. Mar Ecol Prog Ser 203:13-21

Mulholland MR, Glibert PM, Berg GM, Van Heukelem L, Pantoja S, Lee C (1998) Extracellular amino acid oxidation by microplankton: a cross-ecosystem comparison. Aquat Microb Ecol 15:141-152

Mulholland MR, Gobler CJ, Lee C (2002) Peptide hydrolysis, amino acid oxidation and $\mathrm{N}$ uptake in communities seasonally dominated by Aureococcus anophagefferens. Limnol Oceanogr 47:1094-1108

Nagata T (2000) Production mechanisms of dissolved organic matter. In: Kirchman DL (ed) Microbial ecology of the oceans. Wiley-Liss, New York, p 121-152

Nguyen RT, Harvey HR (1994) A rapid microscale method for

Editorial responsibility: Barry and Evelyn Sherr (Contributing Editors), Corvallis, Oregon, USA the extraction and analysis of protein in marine samples. Mar Chem 45:1-14

Nguyen RT, Harvey HR (1997) Protein and amino acid cycling during phytoplankton decomposition in oxic and anoxic waters. Org Geochem 27:115-128

Paerl HW (1988) Nuisance phytoplankton blooms in coastal, estuarine, and inland waters. Limnol Oceanogr 33: 823-847

Palenik BP, Morel FMM (1990a) Amino acid utilization by marine phytoplankton: a novel mechanism. Limnol Oceanogr 35:260-269

Palenik B, Morel FMM (1990b) Comparison of cell-surface Lamino acid oxidases from several marine phytoplankton. Mar Ecol Prog Ser 59:195-201

Palenik B, Morel FMM (1991) Amine oxidases of marine phytoplankton. Appl Environ Microbiol 57:2440-2443

Pantoja S, Lee C (1994) Cell-surface oxidation of amino acids in seawater. Limnol Oceanogr 39:1718-1726

Pantoja S, Lee C (1999) Peptide decomposition by extracellular hydrolysis in coastal seawater and salt marsh sediment. Mar Chem 63:273-291

Pantoja S, Lee C, Marecek JF, Palenik BP (1993) Synthesis and use of fluorescent molecular probes for measuring cell-surface enzymatic oxidation of amino acids and amines in seawater. Anal Biochem 211:210-218

Pantoja S, Lee C, Marecek JF (1997) Hydrolysis of peptides in seawater and sediments. Mar Chem 57:25-40

Parsons TR, Maita Y, Lalli C (1984) A manual of chemical and biological methods for seawater analysis. Pergamon Press, Oxford

Rosso AL, Azam F (1987) Proteolytic activity in coastal oceanic waters: depth distribution and relationship to bacterial populations. Mar Ecol Prog Ser 41:231-240

Sala MM, Karner M, Arin L, Marrase C (2001) Measurement of ectoenzyme activities as an indication of inorganic nutrient imbalance in microbial communities. Aquat Microb Ecol 23:301-311

Sellner KG, Nealley EW (1997) Diel fluctuations in dissolved free amino acids and monosaccharides in Chesapeake Bay dinoflagellate blooms. Mar Chem 56:193-200

Sharp JH (1983) The distribution of inorganic nitrogen and dissolved and particulate organic nitrogen in the sea. In: Carpenter EJ, Capone DG (eds) Nitrogen in the marine environment. Academic Press, New York, p 1-35

Smith DC, Simon M, Alldredge AL, Azam F (1992) Intense hydrolytic enzyme activity on marine aggregates and implications for rapid particle dissolution. Nature 359:139-142

Stepanauskas R, Edling H, Tranvik LJ (1999) Differential dissolved organic nitrogen availability and bacterial aminopeptidase activity in limnic and marine waters. Microb Ecol 38:264-272

Stoecker DK, Gustafson DEJ (2003) Cell surface proteolytic activity of photosynthetic dinoflagellates. Aquat Microb Ecol 30:175-183

Taylor GT (1995) Microbial degradation of sorbed and dissolved protein in seawater. Limnol Oceanogr 40:875-885

Tsugita A, Toyoaki U, Mewes HW, Ataka T (1987) A rapid vapor-phase acid (hydrochloric acid and trifluoroacetic acid) hydrolysis of peptide and protein. J Biochem 102: 1593-1597

Wheeler PA, North B, Littler M, Stephens G (1977) Uptake of glycine by natural phytoplankton communities. Limnol Oceanogr 22:900-909

Submitted: May, 2002; Accepted: April 16, 2003

Proofs received from author(s): August 15, 2003 